\title{
Documenting Hydrological Benefits of Traditional Acequia Irrigation Systems: Collaborative Research in New Mexico, USA
}

\author{
Steven J. Guldan ${ }^{1}$, Alexander G. Fernald ${ }^{1}$, and Carlos G. Ochoa ${ }^{2}$ \\ ${ }^{1}$ New Mexico State University, Las Cruces, New Mexico, USA²Oregon State University, Corvallis, Oregon, \\ USA \\ sguldan@,nmsu.edu, afernald@,nmsu.edu, Carlos.Ochoa@,oregonstate.edu
}

\begin{abstract}
In New Mexico, USA, acequia-based agriculture is under threat as pressures rise to transfer water and land out of agriculture. The amount and cash value of agricultural production coming out of acequia-irrigated valleys is not great when compared to many production areas - yet, the overall value of acequia agricultural systems may go beyond food and fiber production in ways not apparent to the general public. Research on the hydrology of acequias has been carried out in collaboration with acequia associations, irrigators, and other community residents in north-central New Mexico. This research indicates these acequia irrigation systems provide important hydrologic benefits including aquifer recharge and groundwater return flow. In our water budget study, of water diverted into the Acequia de Alcalde, on average only $7 \%$ was consumed by crop evapotranspiration, $59 \%$ returned to the river as surface return flow, and 33\% returned to the river as shallow groundwater return flow. In effect, the acequia irrigation system stores spring snowmelt runoff in the valley alluvial aquifer and releases it to the river later when river flows are normally low. If acequia agriculture decreases significantly, these key hydrologic functions could be lost and fall and winter river flows could diminish, particularly during drought, causing negative effects on downstream water users as well as river ecology.
\end{abstract}

Keywords: Acequia, hydrology, aquifer recharge

\section{Introduction}

In New Mexico, USA, there are about 700 acequias in operation (Saavedra, 1987). These water systems allowed sufficient crop and livestock production to sustain early Spanish settlements in a semiarid climate, and they continue to contribute today to the local economy and culture (Rivera, 1998; Rodríguez, 2006). However, acequia-based agriculture is under threat as pressures rise to transfer water and land out of agriculture.

The Rio Grande Basin that starts in Colorado and drains into the Gulf of Mexico covers much of the state of New Mexico, and the Rio Grande is the main river in the basin. Most of New Mexico's acequias are located in the north-central part of the state. Population growth in the Basin is increasing water demand from municipal, industrial, and other nonagricultural sectors. This demand is often expected to be met by developing policy and other mechanisms that will encourage and facilitate the temporary (Broadbent et al., 2009), or permanent transfer of water rights out of agriculture (Paskus et al., 2012). Residential development puts direct pressure on some acequia agricultural lands. For example, area in irrigated fields along the Acequia de Alcalde decreased 20\% from 1962 to 2003 (Ortiz et al., 2007). In response to the increasing loss of irrigated land to residential and other development, in 2002 Rio Arriba county, in north-central New Mexico, adopted an ordinance placing restrictions on the development of these lands(Rio Arriba Agricultural Protection and Enhancement Ordinance; Adopted January $31^{\text {st }} 2002$; Prepared by the Rio Arriba County Planning and Zoning Department, Rio Arriba County, New Mexico). 
Although crop and livestock production systems supported by acequias have adapted to changing markets and policies in the past, these relatively small farms (typically less than four hectares, often less than two)may also be facing greater weather uncertainty in the future. Simulated results by Hurd and Coonrod (2012) using climate change scenarios indicate a future of greater water scarcity in the upper Rio Grande valley (southern Colorado, New Mexico, and west Texas), with agricultural water users and rural economies being most affected. A current severe drought in New Mexico ${ }^{1}$ compounds the challenges imposed by population growth - state water supplies have decreased while demand continues to rise. For this reason, water diversions for irrigated agriculture in the Rio Grande will likely face increased scrutiny. The amount and cash value of agricultural production coming out of acequia-irrigated valleys is not great when compared to many production areas ${ }^{2}$. Yet, the overall value of acequia agricultural systems may extend beyond food and fiber production (Fernald et al., 2007).

A major goal of our research is to increase understanding of how acequia irrigation agriculture influences surface water-groundwater interactions. Research is taking place in north-central New Mexico and is being carried out in collaboration with acequia associations, irrigators, and other community residents.

\section{Research Questions}

Initial and ongoing research questions related to acequia hydrology that we are addressing include:

1) What is the amount and timing of irrigation canal seepage recharge to shallow groundwater?

2) Is seepage from flood-irrigated fields a significant source of recharge to shallow groundwater?

3) What are contributions of canal and field seepage to groundwater return flow and river flow?

4) What are the projected effects of future management scenarios on timing and magnitude of seepage, groundwater return flow and river flow?

\section{Description of Study Area}

Data were collected from a $20 \mathrm{~km}$ reach of the Rio Grande in north-central New Mexico between Velarde and Ohkay Owingeh Pueblo, New Mexico. Within this reach of the Rio Grande is an irrigated corridor that includes nine acequias providing irrigation water to approximately 900 hectares of cropland (Fernald et al., 2010). Water from the Rio Grande is diverted into the main acequia channels (acequias madre), and then either diverted into smaller irrigation ditches or applied directly to adjacent crop fields. The acequias are located on both sides of the Rio Grande (Fig. 1), and are generally unlined except for relatively short sections of rock, cement, or cement block lining.

\footnotetext{
${ }^{1}$ United States Drought Monitor, National Drought Mitigation Center, http://droughtmonitor.unl.edu/Home/StateDroughtMonitor.aspx?NM

${ }^{2}$ National Agricultural Statistics Service, see county profiles in http://www.nass.usda.gov/Statistics by State/New Mexico/Publications/Annual Statistical Bulletin/bulle tin12.asp
} 


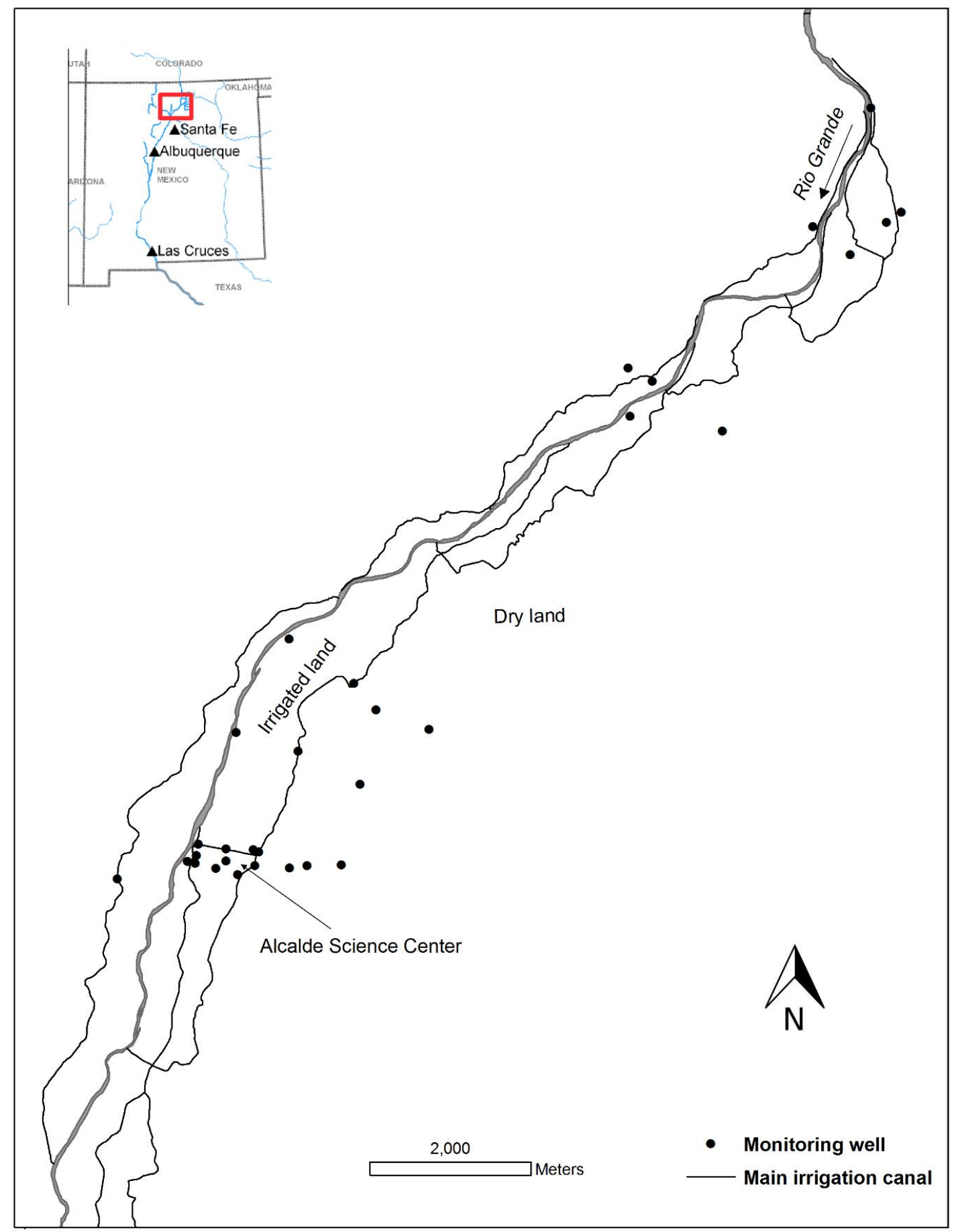

Fig. 1. Map of the study area showing the network of main irrigation canals and monitoring wells used in the research.

Most irrigated area consists of alfalfa and grass forages, but there are also orchards of apples and other tree fruits such as cherries and peaches, in addition to miscellaneous vegetable and specialty crops. Crops are irrigated using primarily surface (border and furrow) irrigation. Most of the water used from Alcalde to Velarde is for agricultural purposes (Ortiz et al., 2007) with about 99\% coming from surface water sources (Cevik, 2009). 
The study area is in the north-central part of the Española Basin (see http://geoinfo.nmt.edu/ebtag/about/About EB.html\#why for a description of the Española Basin) and overlies a shallow unconfined aquifer with depth to water table that generally ranges from $1.5 \mathrm{~m}$ to $10 \mathrm{~m}$ in the irrigated portion of the valley, depending on proximity to the river, and measured when the water table is at its lowest level (before the beginning of the irrigation season). Groundwater flow in the study area is influenced mostly by the Rio Grande and by drainage from tributaries fed from the Sangre de Cristo Mountain Range (part of the Southern Rocky Mountains) in the east side of the basin (Stephens, 2003). The Rio Grande is considered a gaining stream in the study area (Helmus et al., 2009) ${ }^{14}$ and the slope of the water table is around $0.2 \%$ (Ochoa et al., 2009).

Annual precipitation in the study area averages about $250 \mathrm{~mm}$, of which $40 \%$ occurs during the summer season. From 1953 to 2006, the average monthly temperature was $10.6^{\circ} \mathrm{C}$, with the lowest average monthly temperature of $-0.8^{\circ} \mathrm{C}$ during the month of January and the highest average monthly temperature of $22.4^{\circ} \mathrm{C}$ during the month of July ${ }^{3}$. Elevation above mean sea level along the $20 \mathrm{~km}$ river reach of the research area ranged from about $1720 \mathrm{~m}$ to $1764 \mathrm{~m}$. Detailed field-scale studies took place at New Mexico State University's Alcalde Sustainable Agriculture Science Center, at Alcalde, New Mexico. The Center is located between the Acequia de Alcalde and the Rio Grande $\left(36.09^{\circ} \mathrm{N}, 106.06^{\circ} \mathrm{W}\right.$, elev. $\left.1735 \mathrm{~m}\right)$.

\section{Methods}

Individual studies have been directed towards determining and measuring water flows through time and space in the irrigated valley (Fig. 1). Measured flows included diversions from the Rio Grande into all main distribution canals, seepage out of the bed and banks of one of these main canals, the Acequia de Alcalde, percolation of irrigation water below crop fields, crop evapotranspiration, and shallow groundwater level fluctuations. Groundwater levels were monitored at the field scale to determine response to specific irrigation inputs, and at the valley scale to determine general patterns of aquifer recharge.

To carry out several components of the study, it has been critical to have the participation of the acequia associations, farmers, and other community member stakeholders. For example, upon approval by the Acequia de Alcalde commissioners, the mayordomo assisted in altering the flows of the acequia canal to do impoundment tests and for developing rating curves for flow measurements. For valley-scale work, additional acequias assisted and individual community members allowed access to private property and their existing wells (Guldan et al., 2013).

\subsection{Groundwater level monitoring}

Wells for groundwater monitoring included driven-point wells (pounded into the ground) and commercially dug wells installed specifically for the research, as well as community member wells we were allowed to use. Water levels were obtained from manual measurements using water level indicators, but primarily from instruments designed for automated electronic data collection.

\footnotetext{
${ }^{3}$ Western Regional Climate Center (2006): Alcalde, New Mexico (290245), Period of Record Monthly Climate Summary, Period of record 04/01/1953-12/31/2005, http://www.wrcc.dri.edu/cgibin/cliMAIN.pl?nmalca
} 


\subsection{Aquifer recharge}

Two methods were used to determine shallow aquifer recharge at the field scale $(\leq 1 \mathrm{ha})$, the water balance method and the water table fluctuation method (Ochoa et al., 2013). To estimate recharge at the valley scale $\left(\sim 20 \mathrm{~km}^{2}\right)$, the water table fluctuation method was used. In the water balance method, precipitation, irrigation, crop consumption, and runoff were either measured or estimated, and deep percolation was equated to shallow aquifer recharge. In the water table fluctuation method, aquifer recharge is estimated from shallow groundwater level data and fillable porosity of the sand/gravel layer where the monitoring wells are installed (Risser et al., 2005).

\subsection{Water budget for the Acequia de Alcalde}

A water budget approach was used to assess the hydrology of the area served by the Acequia de Alcalde (Fernald et al., 2010):

Acequia diversion $=$ acequia seepage + acequia turnouts + acequia return to river + crop (1)

evapotranspiration + field tailwater + deep percolation

Acequia diversion and acequia return to river. Flow stations near the beginning of the acequia, at a point before any water is diverted for irrigation, and at the end of the acequia where water is diverted back to the river were used to determine the amount of flow entering and exiting the acequia. Acequia flow measurements using a current velocity meter were taken at different acequia water stages (levels) in each of the two flow stations and data collected were used to develop stage/discharge equations for the two flow stations. Stilling wells were installed at each station and were equipped with automated water level loggers. Data collected were related to the stage/discharge equations to obtain hourly estimates of acequia inflow and outflow.

Acequia seepage. Impoundment tests and inflow-outflow tests were used to estimate seepage into the acequia's bed and banks. These tests took place after the regular irrigation season.

Acequia turnouts. Estimates of acequia diversions via turnouts or sluices (desagües)were developed based on data collected from acequia flow measurements using a current velocity meter. These acequia flow measurements were taken on several occasions throughout the duration of the study.

Crop evapotranspiration. Weather data collected at the Alcalde Science Center were used to estimate evapotranspiration for different crops commonly found in the Alcalde-Velarde valley. Over the $10+$ years of this study we have used different methods to calculate evapotranspiration for different crops. For instance, we used the FAO (Food and Agriculture Organization) Penman-Monteith equation (Allen et al., 1998) to estimate crop evapotranspiration in one alfalfa-grass field. Also, for the same alfalfa-grass field and for two oat-wheatgrass crop fields we used the Root Zone Water Quality Model (Ahuja et al., 2000) that uses an extended version of the Shuttleworth-Wallace equation (Shuttleworth and Wallace, 1985) to calculate potential evapotranspiration. In addition, we have used the New Mexico Climate Center (NMCC) webpage to calculate evapotranspiration for alfalfa, wheatgrass, and apple crops. The NMCC used weather data collected at the Alcalde Science Center and the equations by Hargreaves and Samani (1985) and crop coefficients reported by Samani and Pessarakli (1986) for calculating actual evapotranspiration. 
Field tailwater and deep percolation. Field tailwater and deep percolation were estimated based on studies at the Alcalde Science Center (Fernald et al., 2010; Ochoa et al., 2011; Ochoa et al., 2013; Durnford et al., 2006) and were extrapolated to irrigated lands of the Acequia de Alcalde (Fernald et al., 2010). Studies included estimates of surface tailwater off the fields and deep percolation below crop root zones in three of the most common soil types found in the irrigated fields along the Acequia de Alcalde.

\section{Results}

\subsection{Groundwater Response to Irrigation and Aquifer Recharge}

Fig. 2 shows results from a field scale $(0.7 \mathrm{ha})$ study in which groundwater level rose rapidly in response to specific irrigation events during the course of two irrigation seasons. Peaks in groundwater level rise not associated with irrigation events on the field were assumed to be caused by watering of neighboring fields. This soil is classified as a sandy loam. The combination of coarse soil and macropores from alfalfa root channels may have contributed to the rapid movement of water to groundwater in this field.

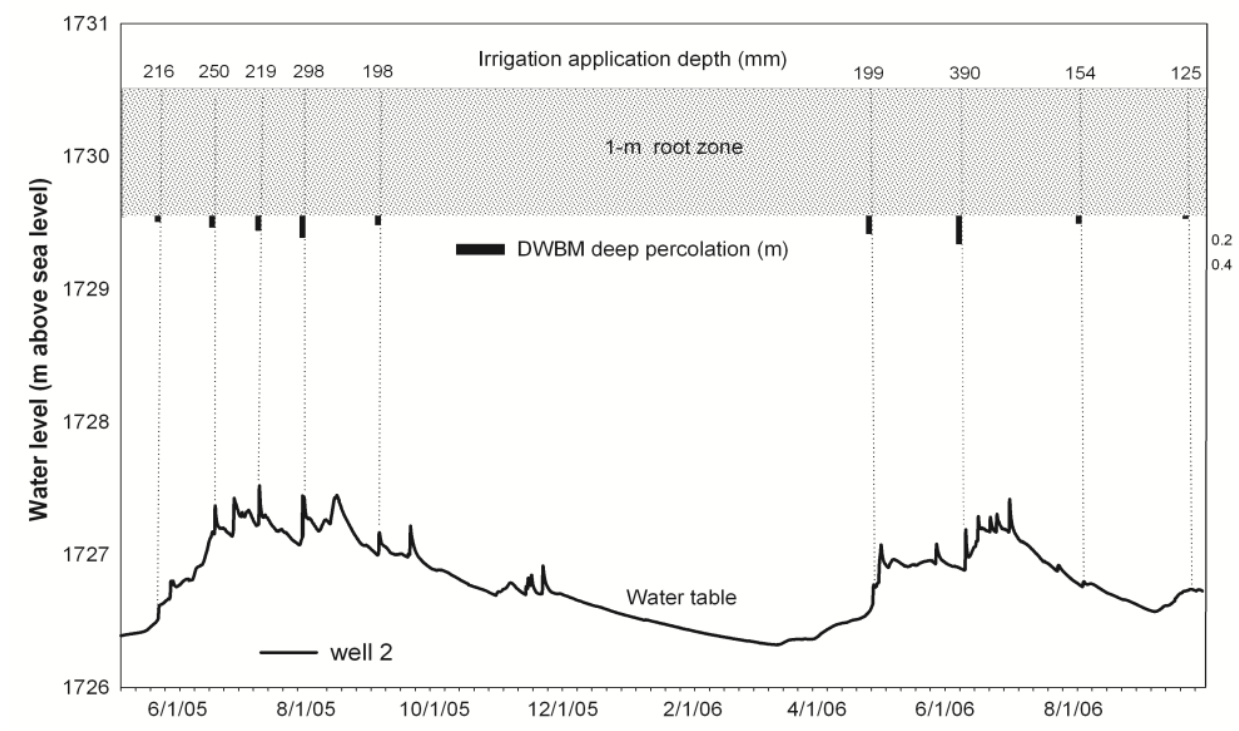

Fig. 2. Seasonal water level fluctuations in one experimental well showing water level response to deep percolation from irrigation inputs. DWBM refers to daily water balance method (Ochoa et al., 2011).

A similar pattern of groundwater level rise during the irrigation season and fall during the off-season was found at the valley scale (Fig. 3). In this study, total irrigation season recharge estimates ranged from 1,044 to $1,350 \mathrm{~mm} /$ year (Ochoa et al., 2013). Data for the beginning of the 2008 irrigation season through the beginning of the following season a year later is shown in Fig. 4, and illustrates groundwater fluctuations as the water management season progresses. After the growing season, when little or no water is diverted to crop fields, the acequias continue to flow for a time to flush out leaves falling from trees along the canals and in some cases as a means to easily water livestock. During this time seepage results primarily via the acequias. When diversion of river water into the acequias ends, groundwater levels continue to drop indicating drainage of groundwater into 
the river and thus continued groundwater return flow to the river during the fall and winter months.

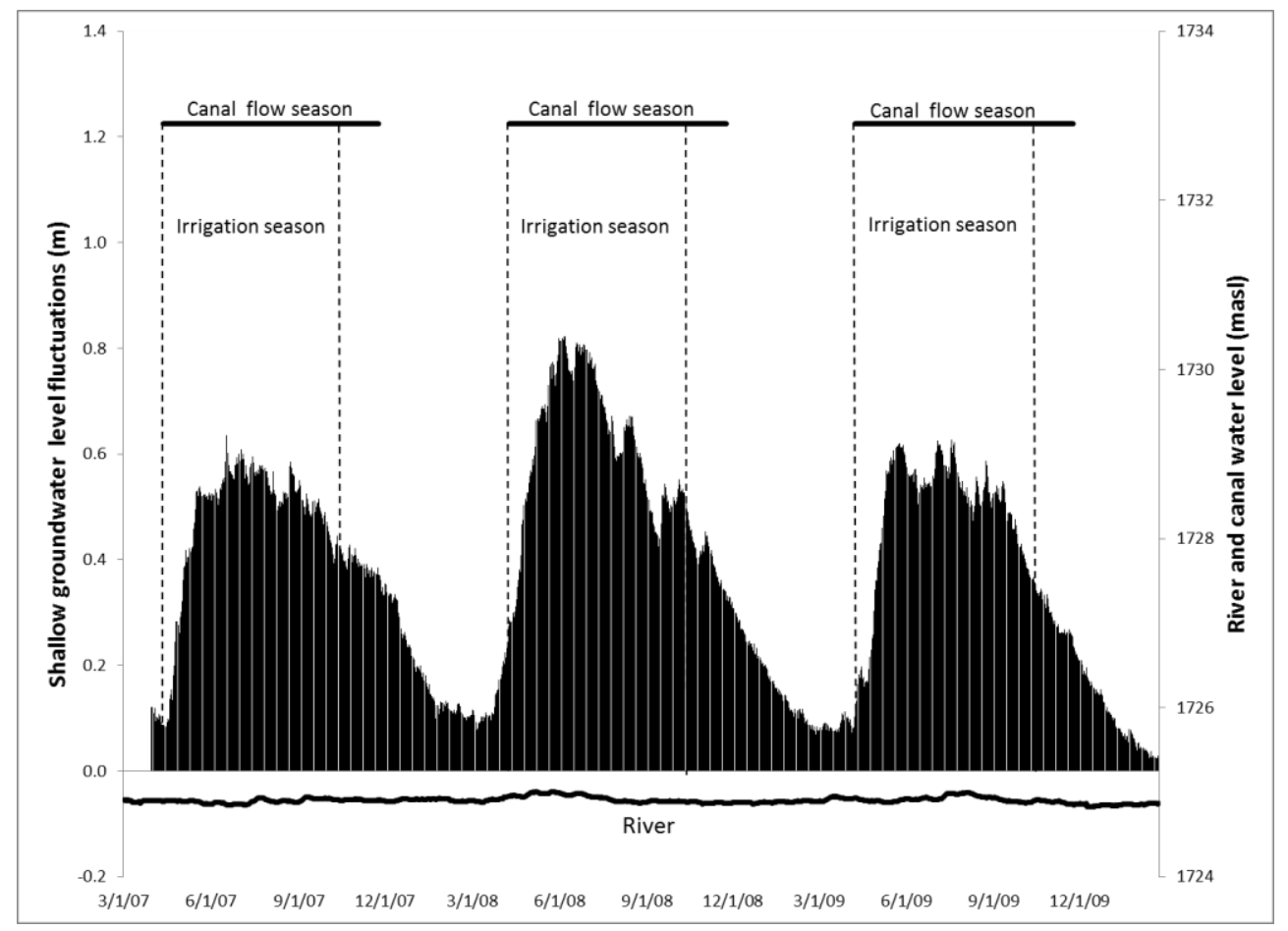

Fig. 3. Shallow-groundwater level fluctuations averaged across 28 monitoring wells in the Alcalde-Velarde valley for years 2007-2009 (Ochoa et al., 2013).

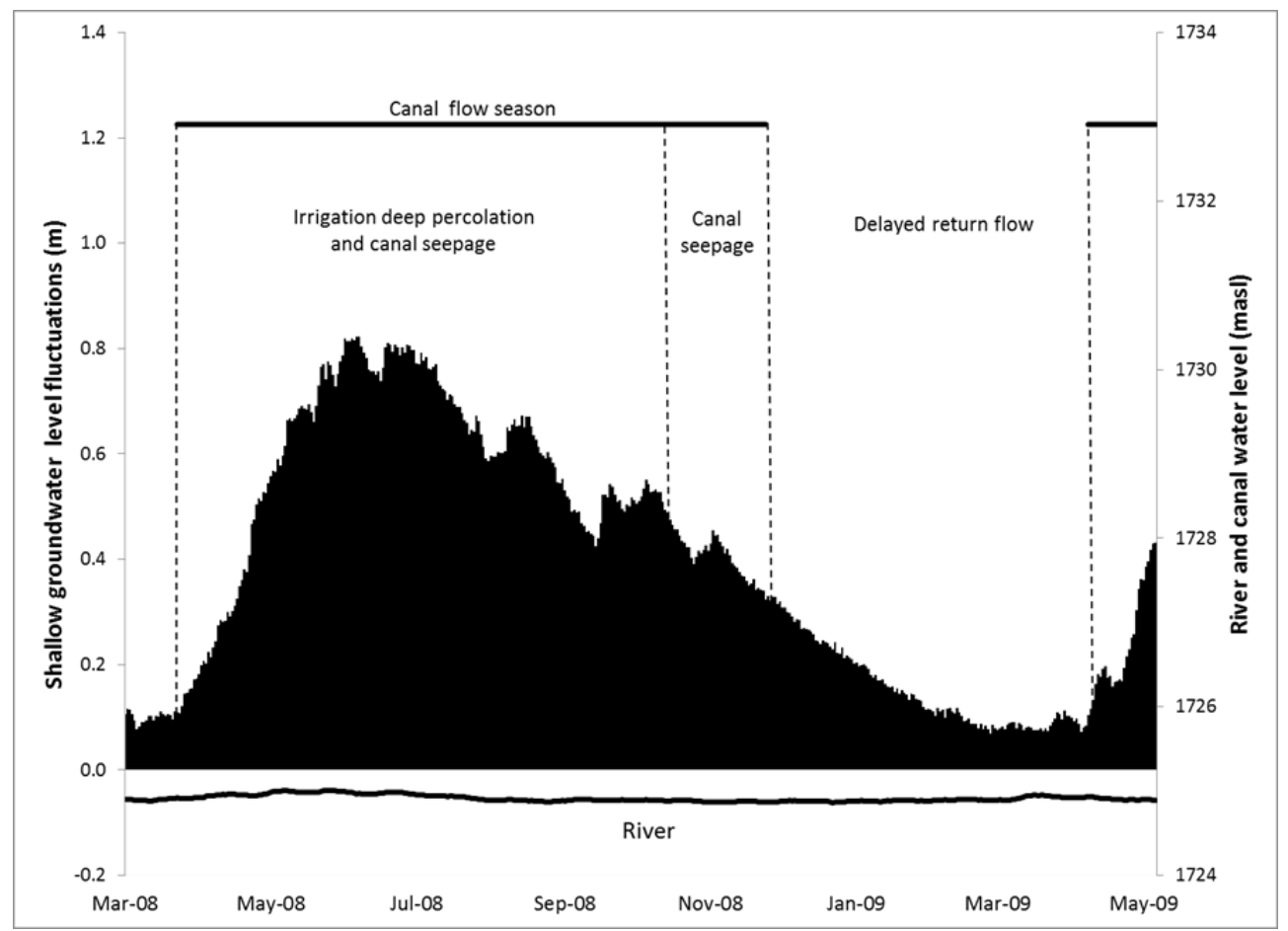

Fig. 4. Shallow-groundwater level fluctuations averaged across 28 monitoring wells in the Alcalde-Velarde valley for the 2008 irrigation season through the beginning of the 2009 season. River and acequia canal water levels are based on the Acequia de Alcalde at the NMSU Alcalde Science Center. 
Aquifer recharge in the vicinity of Alcalde, NM, was found to extend beyond the irrigated floodplain (Fig. 5).For example, the dry land well in the transect that is located $476 \mathrm{~m}$ from the acequia and away from the irrigated floodplain still showed the same seasonal response as the other wells located near the acequia and in the irrigated floodplain. The well in irrigated land exhibited sharp peaks due to specific crop irrigation events. Peaks for the well near the acequia were less defined, and were absent in the dry land well.

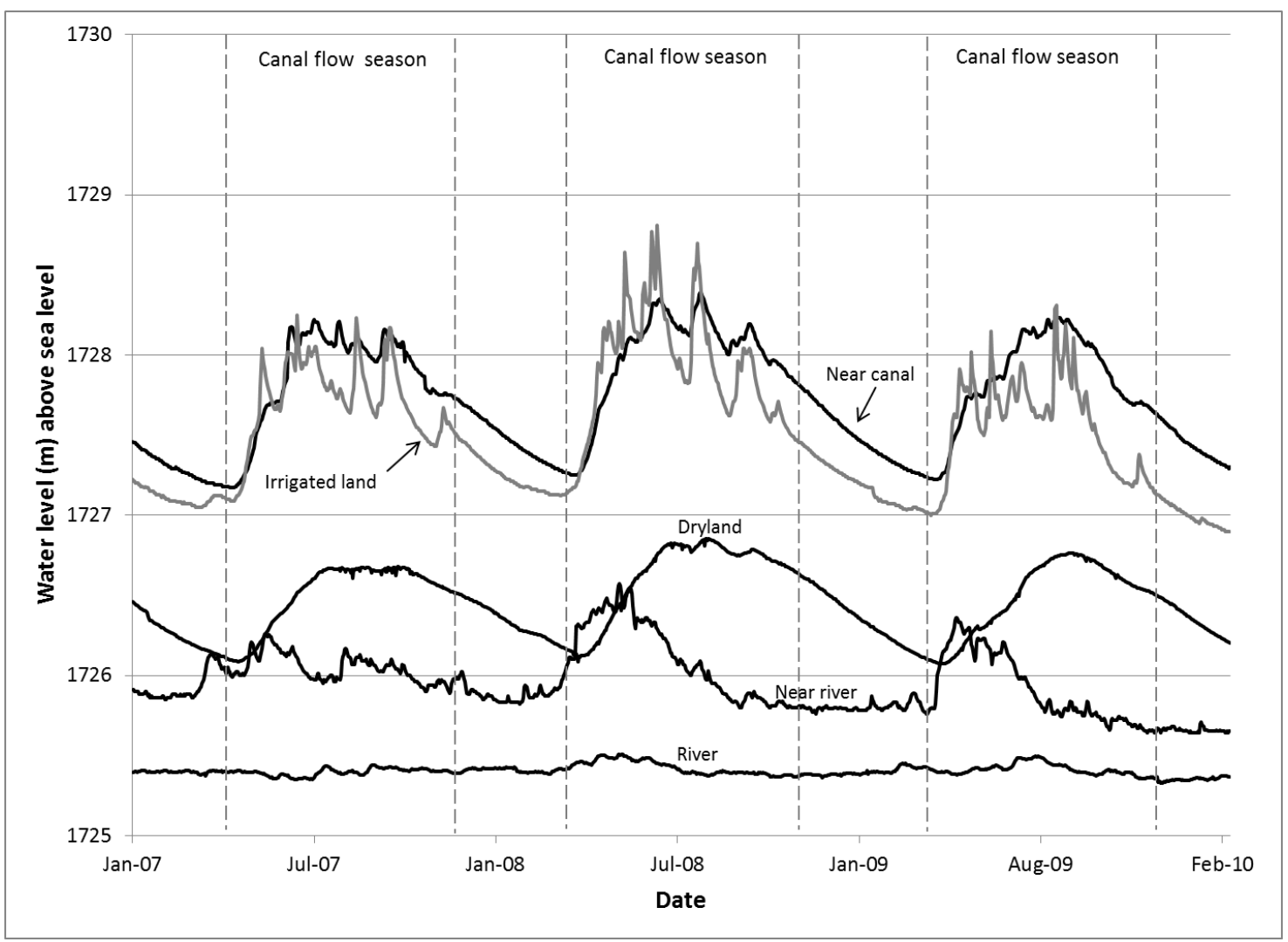

Fig. 5. Water table fluctuations in wells located along one transect; Alcalde, New Mexico. Well distances from the acequia were: dryland $476 \mathrm{~m}$, near canal $3 \mathrm{~m}$, irrigated land $379 \mathrm{~m}$, and near river $749 \mathrm{~m}$ (Ochoa et al., 2013).

\subsection{Acequia de Alcalde Water Budget}

The water budget developed for the Acequia de Alcalde is presented in Table 1.During the three year period of the study, over half of the water diverted into the acequia returned to the river relatively quickly as surface water. Turnouts, or desagües, are used to flush plant debris out of the acequia at the beginning of the irrigation season, control water flows during the season, and allow upstream users to continue to irrigate if maintenance or repairs are needed downstream of a given desagüe. Large amounts of water exit at the end of the acequia (canal outflow), to return to the river. During normal operation, more water than is needed for irrigation is driven through the acequia to provide sufficient flow so users towards the end of the acequia have enough water to irrigate. Also, in many acequias extra flow helps keep the channel clean from leaves and debris that can obstruct sangrias and other smaller water outlets along the acequia. On average, a third of the water was estimated to have made it to the groundwater after first seeping into the soil of the acequia 
and crop fields. As mentioned above, this water is assumed to have drained back to the river underground providing delayed groundwater return flow to the river. On average, less than $10 \%$ of water was lost as crop evapotranspiration.

Table 1. Alcalde Acequia three year (2005-2007) averaged water balance (Fernald et al, 2011).

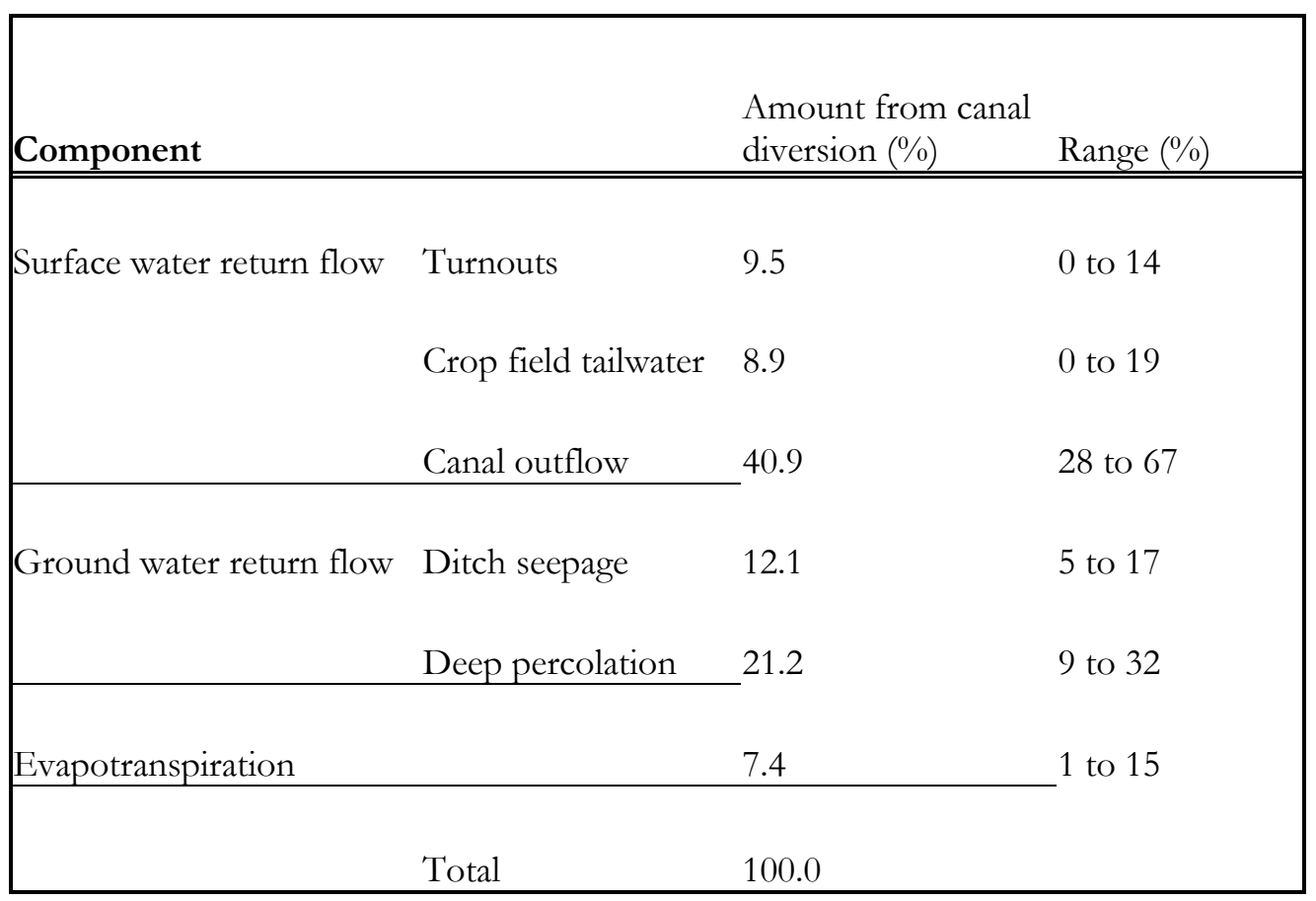

\section{Discussion}

Various factors determine whether irrigation seepage is beneficial or detrimental in a given location. In the case of a losing river, where the river drains into the aquifer system, any loss of seepage out of canals or via deep percolation below fields may not become return flow and reach the river to augment flows. If the groundwater is saline, the seepage water would mix with the saline water and no longer be useable for crops, livestock, or humans if pumped. In cases where agriculture is chemical-intensive, field seepage can carry pesticides and/or excess nutrients such as nitrate nitrogen to the groundwater. Preventing seepage of irrigation water in these situations would normally be important to strive for.

In the Alcalde/Española Valley, there is limited use of pesticides or even synthetic fertilizers. There is also a gaining river condition where seepage and deep percolation replenish the shallow aquifer to such an extent that delayed groundwater return flow to the river results. These appear to be two important hydrologic benefits resulting from acequia agriculture in the valley. Delayed groundwater return flow to the river is especially of interest because of the benefits of maintaining river flows for downstream users and needs including irrigators, municipalities, and riparian vegetation and associated wildlife.In other regions there are situations where expensive projects are carried out to artificially recharge the aquifer to provide stream flow late in the season (Durnford et al., 2006). In the 
Alcalde/Española Valley, recharge occurs as a by-product of traditional irrigation techniques.

The aquifer recharge extending into the dry land area above the floodplain is important for shallow wells of property owners, but is also being considered for an Alcalde community well (David Archuleta, Alcalde Mutual Domestic Water Association, personal communication). A study conducted by Helmus et al. (2009) concluded that water quality in shallow wells is improved because higher quality surface water from irrigation seepage that mixes with groundwater during the irrigation season serves to dilute undesirable ions such as nitrate.

It is significant that only a relatively small percentage of water diverted into the Acequia de Alcalde was lost from crop fields to the atmosphere via evapotranspiration. Some evapotranspiration losses would also result from vegetation growing on acequia banks, although this was not estimated and would not likely be a large amount relative to evapotranspiration from crop fields. River riparian vegetation would also use water resulting from a combination of river seepage and irrigation water seepage sources. The riparian area is expanded because of acequia irrigation systems, and in the semiarid environment of north-central New Mexico, many species of wildlife depend on riparian habit for all or part of their lifecycle (Fernald et al., 2007). A future research goal is to assess riparian evapotranspiration.

If irrigated agriculture declines or is significantly altered in the Alcalde/Española Valley, it is unclear how the Rio Grande hydrograph will change although it will likely mean decreased river flows after the season of spring mountain runoff. Although irrigation is not a natural feature of the landscape, it could be argued that irrigated agriculture maintains hydrologic aspects more similar to the original natural system than if irrigation were to cease. The reason being that due to man-made changes including channelizing the river and construction of flood-control levees, the river no longer meanders, or floods into side channels or the floodplain as before, features that naturally meant more seepage of water into the floodplain, more aquifer recharge, and thus more late-season groundwater return flow. Long term drought would of course also affect aquifer recharge and stream flow patterns, not only as a direct result of less precipitation, but also because of the likely socioeconomic and policy changes that would result and would affect water management and distribution (Fernald et al., 2012).

More research is needed in other irrigated valleys of the Rio Grande to better understand effects of irrigation systems on local and downstream hydrology. If significant hydrologic benefits to the basin as a whole accrue from acequia irrigation systems, it would be an important reason to support these traditional agricultural systems upon which the benefits are based.

\section{Conclusions}

Given the growing concern regarding future water supplies in arid and semiarid regions, it is important to increase our understanding of the hydrology of irrigated agriculture. In north-central New Mexico, research along a $20 \mathrm{~km}$ reach of the Rio Grande indicates that the valley aquifer is being recharged on an annual basis by the seepage resulting from traditional acequias and flood irrigation. The seepage recharge is important for local wells as well as for mixing with and improving the quality of shallow groundwater. After the 
irrigation season, the additional groundwater drains to the river providing late season flow to the river, a time when river flow is normally low. Agricultural production in most acequia irrigated valleys in New Mexico is not great when compared to many production regions. However, aquifer recharge and late-season groundwater return flow are important hydrologic functions resulting from acequia agriculture and provide important hydrologic benefits to downstream municipalities and irrigated agriculture as well as riparian areas, adding importantly to the value of acequias and acequia agriculture. These hydrologic functions could become even more important in the event of long-term drought. Ongoing research seeks to understand the hydrology of acequia irrigation systems under scenarios of long-term drought and climate change.

Acknowledgments. Authors gratefully acknowledge the technical assistance of the NMSUAlcalde Science Center staff, especially David Archuleta, Val Archuleta, David Salazar, and Estevan Herrera. This material is based upon work supported by the Cooperative State Research, Education and Extension Service, U.S. Department of Agriculture under Agreement No. 2005-34461-15661 and 2005-45049-03209, by the National Science Foundation, Award No. 0814449 and Award No. 1010516, and by the New Mexico Agricultural Experiment Station.

\section{References}

Ahuja, L.R., K.W. Rojas, J.D. Hanson, M.J. Shaffer, and L. Ma (2000): Root Zone Water Quality Model: Modeling Management Effects on Water Quality and Crop Production, Water Resources Publications, Highland Ranch, Colorado, USA.

Allen, R.G., L.S. Pereira, D. Raes, and M. Smith (1998): Crop Evapotranspiration: Guidelines for Computing Crop Requirements, Irrigation and Drainage Paper No. 56, FAO, Rome.

Broadbent, C.D., D.S. Brookshire, D. Coursey, and V. Tidwell (2009): Water Leasing: Evaluating Temporary Water Rights Transfers in New Mexico through Experimental Methods, Natural Resources Journal, 49:707-742. http://lawlibrary.unm.edu/nrj/49/3-4/707742.pdf

Cevik, S.Y. (2009): A Long-Term Hydrological Model for the Northern Española Basin, New Mexico,Ph.D. Dissertation, New Mexico State University, Las Cruces, NM.

Durnford, D.S., W.E. Sanford, J.D. Stednick, J. Altenhofen, V. Flory, M. Halstead, G. Fox, J. Watt, W. Law, L. Garcia (2006): Influence of Managed Recharge on Water Quality and Quantity in the South Platte River Basin, Proceedings of the USDA-CSREES National Water Conference, http://www.usawaterquality.org/conferences/2006/presentations/Durnford.pdf

Fernald, A.G., T.T. Baker, and S.J. Guldan (2007): Hydrologic, Riparian, and Agroecosystem Functions of Traditional Acequia Irrigation Systems, Journal of Sustainable Agriculture, 30(2):147-171.

Fernald, A.G., S.Y. Cevik, C.G. Ochoa, V.C. Tidwell, J.P. King, and S.J. Guldan (2010): River Hydrograph Retransmission Functions of Irrigated Valley Surface WaterGroundwater Interactions, Journal of Irrigation and Drainage Engineering, 136:823-835. 
Fernald, A., V. Tidwell, J. Rivera, S. Rodríguez, S. Guldan, C. Steele, C. Ochoa, B. Hurd, M. Ortiz, K. Boykin, and A. Cibils (2012): Modeling Sustainability of Water, Environment, Livelihood, and Culture in Traditional Irrigation Communities and Their Linked Watersheds, Sustainability, 4:2998-3022; doi:10.3390/su4112998.

Guldan, S.J., A.G. Fernald, C.G. Ochoa, and V.C. Tidwell (2013): Collaborative Community Hydrology Research in Northern New Mexico,Journal of Contemporary $W$ ater Research \& Education, 152:49-54.

Hargreaves, G.H., and Z.A. Samani (1985): Reference Crop Evapotranspiration from Temperature, Applied Engineering in Agriculture, 1(2):96-99.

Helmus, A.M., A.G. Fernald, D.M. VanLeeuwen, L.B. Abbott, A.L. Ulery, T.T. Baker (2009): Surface Water Seepage Effects on Shallow Ground-Water Quality Along the Rio Grande in Northern New Mexico, Journal of the American Water Resources Association, 45:407418.

Hurd, B.H., and J. Coonrod (2012): Hydro-Economic Consequences of Climate Change in the Upper Rio Grande, Climate Research, 53:103-118.

Ochoa, C.G., A.G. Fernald, S.J. Guldan, and M.K. Shukla (2007): Deep Percolation and its Effects on Shallow Groundwater Level Rise Following Flood Irrigation, Transactions of the ASABE, 50(1):73-81.

Ochoa, C.G., A.G. Fernald, S.J. Guldan, and M.K. Shukla (2009): Water Movement Through a Shallow Vadose Zone: A Field Irrigation Experiment, V adose Zone Journal, 8:414425.

Ochoa, C.G., A.G. Fernald, and S.J. Guldan (2011): Deep Percolation from Surface Irrigation: Measurement and Modeling using the RZWQM, in M.K. Shukla, Ed., Soil Hydrology, Land Use and Agriculture: Measurement and Modeling, CABI, Wallingford, UK, pp. 231-252.

Ochoa, C.G., A.G. Fernald, S.J. Guldan, V.C. Tidwell, and M.K. Shukla (2013): Shallow Aquifer Recharge from Irrigation in a Semiarid Agricultural Valley in New Mexico, Journal of Hydrologic Engineering, 18:1219-1230.

Ortiz, M., C. Brown, A. Fernald, T.T. Baker, B. Creel, and S. Guldan (2007): Land Use Change Impacts on Acequia Water Resources in Northern New Mexico, Journal of Contemporary Water Research \& Education, 137:47-54.

Paskus, L. (2012): Death By A Thousand Cuts: Will Santa Fe's campaign to buy up water rights kill the Rio Grande?, Santa Fe Reporter, June 27, 2012, http://www.sfreporter.com/santafe/article-6807-death-by-a-thousand-cuts.html

Risser, D.W., W.J. Gburek, and G.J. Folmar (2005): Comparison of Methods for Estimating Ground-Water Recharge and Base Flow at a Small Watershed Underlain by Fractured Bedrock in the Eastern United States, U.S. Geological Survey Scientific Investigations Report 2005-5038, 31 p.

Rivera, J.A. (1998): Acequia Culture: Water, Land, and Community in the Southwest, University of New Mexico Press, Albuquerque, NM, 243 pp.

Rodriguez, S. (2006): Acequia: Water Sharing, Sanctity, and Place, School for Advanced Research Press, Santa Fe, NM, 187 pp. 
Saavedra, P. (1987): Surface Water Irrigation Organizations in New Mexico, Report TDDC-87-2, New Mexico State Engineer Office, Santa Fe, New Mexico,

http://www.nmacequiacommission.state.nm.us/Publications/ose-acequia-rpt1987.pdf

Samani, Z.A., and M. Pessarakli (1986): Estimating Potential Crop Evapotranspiration with Minimum Data in Arizona, Transactions of the ASAE, 29(2):522-524.

Shuttleworth, W.J., and J.S. Wallace (1985): Evaporation from Sparse Crops - An Energy Combination Theory, Quarterly Journal of the Royal Meteorological Society, 111:839-855.

Stephens, D.B. (2003): Jemery Sangre Regional Water Plan, Daniel B. Stephens and Associates, Inc., Albuquerque, NM. 